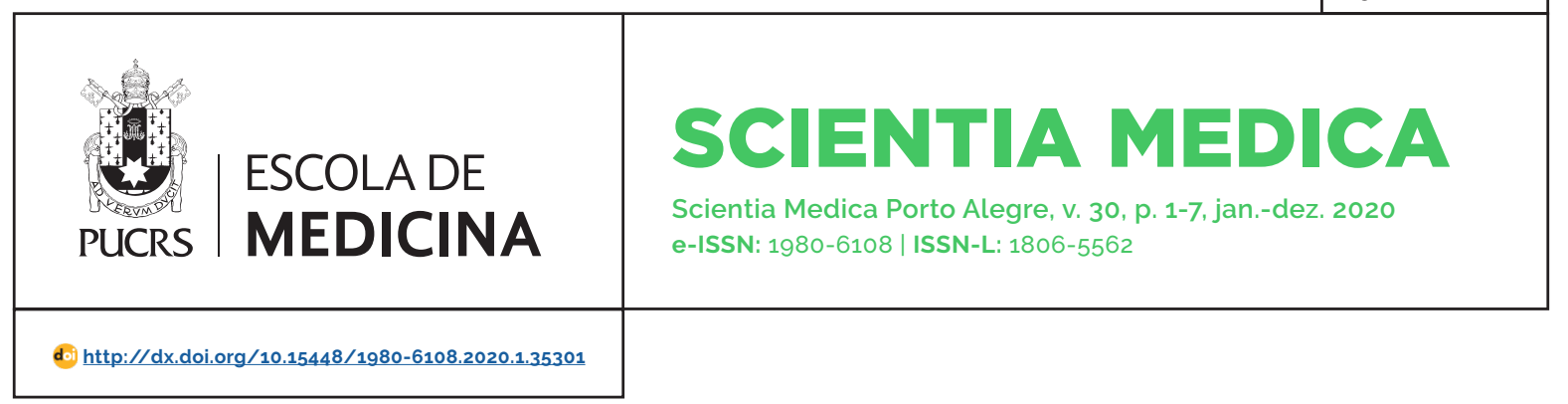

ORIGINAL ARTICLE

\title{
Arm and hand function in hemodialysis patients: A cross sectional analytical study
}

\author{
Função do braço e da mão em pacientes em hemodiálise: um estudo analítico transversal
}

\author{
Danielle Fonseca ${ }^{1}$ \\ orcid.org/0000-0002-9667-918X \\ daniellefonseca.sf@gmail.com
}

\section{Renato Nisihara ${ }^{1}$ \\ orcid.org/0000-0002-1234-8093}

renatonisihara@gmail.com

\section{Jéssica Kavilhuka ${ }^{1}$}

orcid.org/0000-0002-9931-8646 jessicakavilhuka@gmail.com

\section{Paulo Coan Tenorio ${ }^{1}$}

orcid.org/0000-0001-8990-3609 pctenorioi@hotmail.com

\section{Thelma Skare ${ }^{1}$ orcid.org/0000-0002-7699-3542 tskare@onda.com.br}

Recebido em: 12 ago. 2019 Aprovado em: 15 nov. 2019 Publicado em: 25 mar. 2020

\section{(c) (i)}

Artigo está licenciado sob forma de uma licença Creative Commons Atribuiccão 4.0 Internacional.

\section{Abstract \\ Aims: To investigate the arm and hand function in hemodialysis patients.} Methods: Upper limb function using validated questionnaires such as Disabilities of the Arm, Shoulder and Hand Questionnaire (DASH), Cochin and Boston were applied to 57 chronic renal failure patients on hemodialysis and 60 healthy controls. Epidemiological data, data on pain and paresthesia in the upper limb and handgrip strength were obtained.

Results: The three questionnaires showed worse performance of upper limb function in chronic renal failure patients than controls: DASH questionnaire with $P=0.05$; Cochin questionnaire with $P=0.0004$ and Boston questionnaire with $P$ $=0.03$. The questionnaire scores were affected by presence of pain $(P=0.05$ for DASH and $<0.0001$ for Boston questionnaires) and paresthesia (DASH with $\mathrm{P}=$ 0.003 : Cochin with $\mathrm{P}=0.01$ and Boston questionnaire with $\mathrm{P}<0.0001$ ). Handgrip strength was lower in hemodialysis patients when compared with controls $(\mathrm{P}=$ 0.02 ) but did not affect the performance of any of the studied questionnaires.

Conclusions: Upper limb function is impaired in hemodialysis patients and the main associations found were with pain and paresthesia.

Keywords: Hemodyalisis; Arteriovenous fistula; Pain; Paresthesia; Hand.

\section{Resumo}

Objetivos: Investigar a função do braço e da mão em pacientes em hemodiálise. Métodos: A função dos membros superiores foi investigada utilizando-se questionários validados, como Disability of the Arm, Shoulder and Hand Questionnaire (DASH), Cochin e Boston, sendo aplicada a 57 pacientes com insuficiência renal crônica em hemodiálise e 60 controles saudáveis. Foram obtidos dados epidemiológicos tais como dor e parestesia no membro superior e força de preensão manual.

Resultados: Os três questionários apresentaram pior desempenho da função do membro superior em pacientes com insuficiência renal crônica do que os controles: questionário DASH com $\mathrm{P}=0,05$; questionário de Cochin com $\mathrm{P}=$ 0,0004 e questionário de Boston com $\mathrm{P}=0,03$. Os escores do questionário foram afetados pela presença de dor $(\mathrm{P}=0,05$ para DASH e $<0,0001$ para questionários de Boston) e parestesia (DASH com $\mathrm{P}=0,003$; Cochin com $\mathrm{P}=0,01$ e Boston com $\mathrm{P}<0,0001)$. A força de preensão manual foi menor nos pacientes em hemodiálise quando comparados aos controles $(P=0,02)$, mas não afetou o desempenho de nenhum dos questionários estudados.

Conclusões: A função do membro superior é prejudicada em pacientes em hemodiálise e as principais associações encontradas foram com dor e parestesia.

Palavras chave: Hemodiálise; fístula arteriovenosa; dor; parestesia; mão.

Abreviattions: $\mathrm{Cl}$, confidence interval; $\mathrm{CRF}$, Chronic renal failure; $\mathrm{A}-\mathrm{V}$, arteriovenous; DASH, Disabilities of the Arm, Shoulder and Hand; IQR, interquartile range: VAS, visual analogic scale. 


\section{INTRODUCTION}

Good function of the arms and hands is essential to accomplish tasks that are necessary for daily living. Chronic renal failure (CRF) patients on hemodialysis may have important loss of upper extremities function [1] with impairment of their independence and quality of life. Several factors may contribute to this loss of function. Sarcopenia with consequent muscle weakness [2-4], uremic polyneuropathy [5] and electrolyte imbalance [4] are common in patients with renal failure. Local factors, such as the arteriovenous (A-V) fistula required for the hemodialysis procedures, may cause musculoskeletal [6] and neuronal ischemia [7] by modifications in the local blood flow and promote limb edema favoring the appearance of carpal tunnel syndrome. Amyloidosis by B-2 microglobulin deposition in tendons, carpal tunnel, bone and joints causes pain and inflammation leading to musculoskeletal dysfunction [8].

Several studies have focuses in grip strength modifications in CRF patients on dialysis showing that loss of hand strength may be a good measure of protein energy wasting which is characterized by loss of muscle mass associated with inflammation $[2,4]$. So, loss of hand grip strength reflects patients' general frailty predicting their survival [2]. However, studies on the performance of upper limb of CRF patients are scanty. This study aimed to study the upper limb function of patients in hemodialysis correlating with epidemiological and clinical variables.

\section{METHODS}

Study design and subjects: This is a cross sectional study that included 57 patients with CRF on hemodialysis and with $A-V$ fistula, from a single dialysis center. This is a convenience sample of patients that come for regular treatment for one-year period and that agreed to participate in the study. As control, 60 auto declared healthy individuals that were patient's companions were included, matched with the study group for gender, age, member dominance and type of work (manual versus non-manual).

Ethical statements: The local Committee of
Ethics in Research approved the study under protocol number CAAE 52974016.2.0000.0103 in February 17, 2016. All patients were older than 18 years of age and signed consent. The Helsinki ethical principles for medical research involving human subjects were followed.

Exclusion criteria: We excluded patients with prior neurological, rheumatological and orthopedic upper limb problems, patients who have had surgery of upper limbs, women with mastectomy and patients with diabetes mellitus. Patients doing hemodialysis through catheter were also excluded.

Data collection: Patients were submitted to a structured questionnaire that included: epidemiological variables (age, race, gender, work, use of tobacco); clinical data (cause of $\mathrm{CRF}$, hemodialysis duration; local of A- $\mathrm{V}$ fistula; presence of pain and paresthesia in the upper limbs graded in a visual analogic scale (VAS) from 0 to 10 (where o means no symptoms and 10 the worst scenario).

Patients and controls answered the Disabilities of the Arm, Shoulder and Hand (DASH) questionnaire [9], Cochin hand functional scale [10] and the Boston questionnaire [11] that were translated and validated for the Portuguese language.

The DASH questionnaire [9] was developed to measure physical disability and symptoms of the upper limbs as a whole. It contains 30 questions including items related to symptoms and to physical and social function. Optional modules for musicians, athletes and workers may be used. Its score is calculated by applying established formulas, one of them used to analyze the first 30 questions and the other for the optional modules. In the present study, we did not use the optional modules. The DASH score without optional modules ranged from 25 (mild disability) to 125 (severe disability).

The Cochin hand functional scale [10] is an instrument with of 18 questions that is designed to assess functional disabilities of the hands. Each question has a score from zero to five in a Likert scale. Total scores are obtained by the sum of individual scores. It goes from o to 90 where zero means no disability and 90 the worst scenario. 
The Boston Carpal Tunnel questionnaire [11] is used in patients with carpal tunnel syndrome to access symptom severity and the degree of manual disability. Each item has five answer options distributed in a Likert scale (from 1 to 5). The total score is obtained by the sum of the individual score of each item divided by the number of answers. Final scores range from 1 to 5 with higher scores indicating a greater degree of disability and a more severe form of the disease.

Measurement of both arms and forearms diameters with an inelastic tape, $10 \mathrm{~cm}$ above and $10 \mathrm{~cm}$ under the elbow's medial epicondyle was done in all patients.

Handgrip was measured in triplicate, just prior to the dialysis, with the patients seating, and with shoulders neutrally rotated and adducted, elbow flexed at $90^{\circ}$, forearm in neutral position and wrist between 0 and $30^{\circ}$ of dorsiflexion [12], using a Jamar ${ }^{\circledR}$ dynamometer. For statistical analysis, the highest value was considered. This grip measurement was done only in the dominant member of patients with A-V fistula in the non-dominant side. Tinel's and Phallen' tests, for carpal tunnel syndrome, were performed according previously described.

Statistical studies: Data was collected in contingency and frequency tables. Data distribution was studied by Shapiro Wilks test. Central tendency was expressed in mean and standard deviation when data was parametric and median with interquartile range (IQR) when it was nonparametric. Comparison of nominal data was done by chi-squared test and of numeric data by Mann Whitney tests. Correlation studies were done by Spearman test. The adopted significance was of $5 \%$.

\section{RESULTS}

\section{Sample description}

Epidemiological data of studied sample and pairing with controls is on Table 1.

In the hemodialysis group, the A-V fistula was the arm in 36/57 (63.1\%) and in the forearm in 21/57 (36.8\%); in the non-dominant member in $42 / 57(73.6 \%)$.

The median hemodialysis duration was of 4.0 (IQR $=1.4-8.5)$ years. The median difference in diameter in the forearm (between right and left side) was of $1.0(I Q R=0.5-2.0) \mathrm{cm}$ and in the arm was $1.0(I Q R=0.5-2.1) \mathrm{cm}$.

In the hemodialysis sample 24/57 (42.1\%) complained of pain in the arms (median VAS = $6.0 ; I Q R=3.0-7.6)$ and $17 / 57$ (29.8\%) of paresthesia (median VAS $=7.5 ;$ IQR $=5.0-7.5)$. Only 6/17 (35.2\%) of patients with paresthesia or $6 / 57$ (1.0\%) of the whole sample of patients in hemodialysis described the symptoms in the median nerve pathway.

TABLE 1 - Pairing data of hemodialysis patients and controls

\begin{tabular}{|c|c|c|c|}
\hline & Hemodialysis patients & Controls & $P$ \\
\hline Number of individuals & 57 & 60 & \\
\hline Female/male & $22 / 35$ & $28 / 32$ & $0.10^{*}$ \\
\hline Median age (IQR) - years & $47(36.0-56.0)$ & $41.5(28.2-55.7)$ & $0.16^{+}$ \\
\hline Right side dominance, n (\%) & $53(92.8)$ & $57(95)$ & $0.71^{*}$ \\
\hline Work manual/non-manual & $50 / 7$ & $53 / 7$ & $0.91^{*}$ \\
\hline \multicolumn{4}{|l|}{ Ethnic background, n (\%) } \\
\hline Asian: & 0 & $2(3.3)$ & $0.17^{*}$ \\
\hline Eurodescendants: & $49(85.9)$ & $54(90)$ & \\
\hline Afrodescendants: & $8(14.0)$ & $4(6.6)$ & \\
\hline Tobbaco exposure & $29(50.8)$ & $21(35)$ & $0.09^{*}$ \\
\hline
\end{tabular}

* chi-squared test; + Mann Whitney test.

$\mathrm{IQR}=$ interquartile rate. 
Comparison of upper limb performance of hemodialysis patients and controls and study of epidemiological and clinical variables influence in the questionnaires results

The comparison of DASH, Cochin and Boston questionnaire in CRF individuals and controls is seen on Table $\mathbf{2}$ where it is possible to note the worse performance of upper limb function in hemodialysis patients according to the three instruments.

TABLE 2 - Comparison of questionnaires results (median and interquartile rate) for upper limb function in hemodialysis patients.

\begin{tabular}{llcc}
\hline & Hemodialysis & Controls & $P^{*}$ \\
\hline DASH score $^{+}$ & $40.0(31.6-57.2)$ & $31.6(30.0-37.2)$ & .05 \\
Cochin score $^{+}$ & $1(0-5.5)$ & $0(0-0)$ & .0004 \\
Boston questionnaire score & $1.28(1-2)$ & $1.0(1-1.5)$ & .03 \\
\hline
\end{tabular}

"Mann Whitney test. ${ }^{+}$Median (interquartile rate)

DASH = Disabilities of the Arm, Shoulder and Hand Questionnaire. IQR = interquartile rate:

The study of questionnaires scores according to $A-V$ fistula localization is seen on Table 3. The A-V fistula localization neither in the arm or the forearm, nor in dominant or non-dominant member affects the result of questionnaires. However, pain and paresthesia were associated with worse upper limb performance as seen in Table 4.

TABLE 3 - Comparison of upper limb function questionnaires scores (median and interquartile rate) according to localizations of hemodialysis A-V fistula

\begin{tabular}{|c|c|c|c|c|c|c|}
\hline Score & Arm & Forearm & $\mathrm{P}^{*}$ & $\begin{array}{c}\text { Dominant } \\
\text { member } \\
n=15\end{array}$ & $\begin{array}{c}\text { Non-dominant } \\
\text { member } \\
n=42\end{array}$ & $p^{*}$ \\
\hline $\mathrm{DASH}^{+}$ & $\begin{array}{c}36.2 \\
(30.2-49.1)\end{array}$ & $\begin{array}{c}33.3 \\
(28.3-59.5)\end{array}$ & 0.72 & $\begin{array}{c}37.5 \\
(31.6-58.1)\end{array}$ & $\begin{array}{c}43.3 \\
(34.3-53.5)\end{array}$ & .83 \\
\hline Cochin ${ }^{+}$ & $\begin{array}{c}0 \\
(0-5.5)\end{array}$ & $\begin{array}{c}1 \\
(0-6.5)\end{array}$ & 0.65 & $\begin{array}{c}2.0 \\
(0-9)\end{array}$ & $\begin{array}{c}0.5 \\
(0-3.5)\end{array}$ & .48 \\
\hline $\begin{array}{c}\text { Boston } \\
\text { questionnairet }\end{array}$ & $\begin{array}{c}1.18 \\
(1-2.2)\end{array}$ & $\begin{array}{c}1.0 \\
(1-2)\end{array}$ & 0.31 & $\begin{array}{c}1.18 \\
(1.0-2.2)\end{array}$ & $\begin{array}{c}1.04 \\
(1-1.2)\end{array}$ & .41 \\
\hline
\end{tabular}

"Mann Whitney test; ${ }^{+}$Median (interquartile rate)

DASH = Disabilities of the Arm, Shoulder and Hand Questionnaire. 
TABLE 4. -Comparison of upper limb function questionnaires scores (median and interquartile rate) in hemodialysis patients according to presence of pain and paresthesias

\begin{tabular}{|c|c|c|c|c|c|c|}
\hline & With pain & $\begin{array}{l}\text { Without } \\
\text { pain }\end{array}$ & $P^{*}$ & $\begin{array}{c}\text { With } \\
\text { paresthesias }\end{array}$ & $\begin{array}{c}\text { Without } \\
\text { paresthesias }\end{array}$ & $p^{*}$ \\
\hline $\mathrm{n}$ & 24 & 33 & & 17 & 44 & \\
\hline $\mathrm{DASH}^{+}$ & $\begin{array}{c}66.6 \\
(32.2-79.3)\end{array}$ & $\begin{array}{c}35.0 \\
(29.1-47.5)\end{array}$ & .05 & $\begin{array}{c}61.6 \\
(40.4-80.4)\end{array}$ & $\begin{array}{c}34.5 \\
(28.3-41.6)\end{array}$ & .003 \\
\hline Cochin score & $\begin{array}{c}1.0 \\
(0-10.5)\end{array}$ & $\begin{array}{c}0 \\
(0-4.5)\end{array}$ & .37 & $\begin{array}{c}2.0 \\
(0.5-15.0)\end{array}$ & $\begin{array}{c}0 \\
(0-2.7)\end{array}$ & .01 \\
\hline $\begin{array}{c}\text { Boston } \\
\text { questionnaire }\end{array}$ & $\begin{array}{c}2.3 \\
(2.0-3.2)\end{array}$ & $\begin{array}{c}1.8 \\
(1.8-1.8)\end{array}$ & $<.0001$ & $\begin{array}{c}4.9 \\
(4.2-5.0)\end{array}$ & $\begin{array}{c}2.09 \\
(1.8-2.4)\end{array}$ & $<.0001$ \\
\hline
\end{tabular}

* Mann Whitney test. ${ }^{*}$ Median (interquartile rate) $I Q R=$ interquartile rate.

Correlation studies of the three questionnaires with patients' age, hemodialysis duration, differences in diameters of the arm and in the forearm were all non-significant.

To obtain a homogeneous group to study the influence of handgrip in upper limb performance we considered only the sample of patients with A- $V$ fistula in the non-dominant arm $(n=42)$.

Regarding hand grip, patients' median strength of dominant arm was of $30.0 \mathrm{mmHg}(I Q R=18.9-38.0$ $\mathrm{mmHg}$ ); controls had a median value of $34 \mathrm{mmHg}$ $(I Q R=26.0-45 \mathrm{mmHg})$ with $\mathrm{P}=0.02$. No correlation was found of handgrip in hemodialysis patients with DASH scores ISpearman rho $=-0.16 ; 95 \%$ confidence interval $(\mathrm{Cl})=-0.46$ to $0.16 ; P=0.32$, Cochin scores (Spearman rho $=-0.04 ; 95 \% \mathrm{Cl}=-0.36$ to $0.27 ; \mathrm{P}=$ 0.76) or Boston questionnaire results (Spearman rho $=-0.06 ; 95 \% \mathrm{Cl}=-0.38$ to $0.26 ; \mathrm{P}=0.67$.

\section{DISCUSSION}

Our results showed that hemodialysis patients have more difficulties with the upper limb function when compared to healthy controls. This finding was evident in the three used questionnaires, displaying that these problems occur with the function of the whole upper limb (DASH questionnaire) [9] as well as with the hands or extremities (studied by Cochin
[10] and Boston questionnaires [11].

We also have found that pain and paresthesia, but not the A-V fistula localization as we hypothesized initially, were associated with worse score of the applied instruments. Osteomalacia, osteitis fibrosa cystica, amyloidosis, osteoarthritis, calcific uremic arteriolopathy and peripheral neuropathy are causes of limb pain in patients with CRF [13]. Also, comorbidities such as ischemic peripheral artery disease may contribute to this symptom [13]. In our sample, almost half (41.2\%) of the patients complained of pain of relative high intensity (mean VAS score of 6.0).

Paresthesias, the hallmark of neuronal involvement, may be caused by carpal tunnel involvement [14], nerve hypoxia due to ischemia by the A-V fistula [6] or by uremic neuropathy $[15,16]$. According to the literature carpal nerve syndrome is seen in $2 \%$ to $30 \%$ of patients [17,18] and may be due to limb edema caused by the $A-V$ fistula or to deposition of Beta 2 amyloid [19]. We did not have electrophysiological studies to know the exact prevalence of carpal tunnel syndrome in this sample. About $1 \%$ of our patients described paresthesias in the median nerve area, but it is possible that the prevalence of carpal tunnel syndrome was much higher than this, as not all 
patients pay attention to the real distribution of the symptoms. Other causes of paresthesia may be the nerve ischemia associated with $\mathrm{A}-\mathrm{V}$ fistula presence [20] and uremic polyneuropathy [15]. The pathophysiology of hand ischemia due to A-V fistula is partly unclear [21] Some explanations are a very low forearm and hand blood pressures associated with turbulent flow at the $\mathrm{A}-\mathrm{V}$ anastomosis [20] or stealing of blood away from the high-resistance forearm arteries into the low-resistance arteriovenous access [21].

Interestingly handgrip, although impaired in the hemodialysis patients, could not be linked to upper limb dysfunction. With these results, it is possible to assume that the main determinant of upper limb dysfunction is not muscle weakness but neuronal damage causing pain and difficulty to perform movements. The finding that hemodialysis duration was associated with Cochin results, that measures distal upper limb function, but not with DASH, that includes proximal limb function, corroborates this hypothesis. It is well known that distal limb involvement is affected rather in peripheral neurological disease than in muscular disorders [22].

Limitations to this study is its cross-sectional design and the small number of the sample. On the other hand, we were very restrictive in the inclusion of patients not allowing the participation of diabetics as diabetic neuropathy could cause an interpretation bias.

Concluding, we found that CRF patients on hemodialysis have impairment of hand function that is associated with pain and paresthesia but not with handgrip strength. Caring for pain treatment may help to improve these patients' quality of life.

\section{Notes \\ Funding}

This study did not receive financial support from external sources

\section{Conflicts of interest disclosure}

The authors declare no competing interests relevant to the content of this study.

\section{Authors' contributions.}

All the authors declare to have made substantial contributions to the conception, or design, or acquisition, or analysis, or interpretation of data; and drafting the work or revising it critically for important intellectual content; and to approve the version to be published.

\section{Availability of data and responsibility for the results}

All the authors declare to have had full access to the available data and they assume full responsibility for the integrity of these results.

\section{REFERENCES}

1. Rehfuss JP, Berceli SA, Barbey SM, He Y, Kubilis PS, Beck AW, Huber TS, Scali ST. The spectrum of hand dysfunction after hemodialysis fistula placement. Kidney Int Rep. 2017;2(3):332-41. PMID: 28845469; https://doi.org/10.1016/j.ekir.2016.11.006

2. Vogt BP, Borges MCC, Goés CR, Caramori JCT. Handgrip strength is an independent predictor of all-cause mortality in maintenance dialysis patients. Clin Nutr. 2016;35(6):1429-33. PMID: 27083497; https://doi.org/10.1016/j.clnu.2016.03.020

3. Kang SH, Lee HS, Lee S, Cho JH, Kim JC. Comparison of muscle mass indices using computed tomography or dual x-ray absorptiometry for predicting physical performance in hemodialysis patients. Kidney Blood Press Res. 2017:42(6):1119-27. PMID: 29224021; https://doi.org/10.1159/000485779

4. Leal VO, Mafra D, Fouque D, Anjos LA. Use of handgrip strength in the assessment of the muscle function of chronic kidney disease patients on dialysis: a systema tic review. Nephrol Dial Transplant. 2011;26(4):1354-60. PMID: 20709742 https://doi. org/10.1093/ndt/gfa487

5. Lacerda G, Krummel T, Hirsch E. Neurologic presentations of renal diseases. Neurol Clin. 2010;28(1):45-59. PMID: 19932375; https://doi.org/10.1016/j.ncl.2009.09.003

6. Vaes RH, Tordoir JH, Scheltinga MR. Blood flow dynamics in patients with hemodialysis access-induced hand ischemia. J Vasc Surg. 2013:58(2):44651.e1. PMID: 23796414; https://doi.org/10.1016/j. jvs.2013.01.032

7. Talebi M, Salari B, Ghannadan H, Kakaei F, Azar SA. Nerve conduction changes following arteriovenous fistula construction in hemodialysis patients. Int Urol Nephrol. 2011;43(3):849-53. PMID: 20419395; https:// doi.org/10.1007/s11255-010-9740-9

8. Corlin DB, Heegaard NH. (2)-microglobulin amyloidosis. Subcell Biochem. 2012; 65: 517-40. doi: 10.1007/978-94-007-5416-4. 
9. Orfale AG, Araújo PM, Ferraz MB, Natour J. Translation into Brazilian Portuguese, cultural adaptation and evaluation of the reliability of the Disabilities of the Arm, Shoulder and Hand Questionnaire. Braz J Med Biol Res. 2005;38(2): 293-302. PMID: 15785841; https://doi.org/10.1590/s0100-879×2005000200018

10. Chiari A, Sardim CCS, Natour J. Translation, cultural adaptation and reproducibility of the Cochin Hand Functional Scale questionnaire for Brazil. Clinics. 2011;66(5):731-6. PMID: 21789372. https://doi. org/10.1590/s1807-59322011000500004

11. de Campos CC, Manzano GM, de Andrade LB, Castelo Filho A, Nóbrega JA. Translation and validation of an instrument for evaluation of severity of symptoms and the functional status in carpal tunnel syndrome. Arq Neuropsiquiatr. 2003; 61(1):51-5. PMID: 12715019

12. Mendes J1, Amaral TF, Borges N, Santos A, Padrão P, Moreira P, Afonso C, Negrão R. Handgrip strength values of Portuguese older adults: a population based study. BMC Geriatr. 2017;17(1):191. PMID: 2883521 https://doi.org/10.1186/s12877-017-0590-5

13.Santoro D, Satta E, Messina S, Costantino G, Savica V, Bellinghieri G. Pain in end-stage renal disease: a frequent and neglected clinical problem Clin Nephrol. 2013:79 Suppl 1:S2-11. PMID: 23249527. https://doi.org/10.5414/cnX77s104

14. Kang HJ, Koh IH, Lee WY, Choi YR, Hahn SB. Does carpal tunnel release provide long-term relief in patients with hemodialysis-associated carpal tunnel syndrome? Clin Orthop Relat Res. 2012;470(g):2561-5. PMID: 22399438;. https://doi.org/10.1007/s11999-

012-2309-4

15. Ku do Y, Park YS, Chang HJ, Kim SR, Ryu JW, Kim WJ. Depression and life quality in chronic renal failure patients with polyneuropathy on hemodialysis. Ann Rehabil Med. 2012;36(5):702-7. PMID: 23185736;. https://doi.org/10.5535/arm.2012.36.5.702

16. Basturk T, Koc Y, Kayalar AO, Yilmaz F, Hasbal NB, Sakaci T, Ahbap E, Unsal A. Frequency of polyneuropathy in patients on long term peritoneal dialysis treatment. J Clin Diagn Res. 2017:11(6):OC37-OC40. PMID:28764223:

17. Fujita K, Kimori K, Nimura A, Okawa A, Ikuta Y. MR analysis of carpal tunnel syndrome in hemodialysis patients versus non-hemodialysis patients: a multicenter case-control study. J Orthop Surg Res. 2019; 14: 91https://doi.org/10.1186/s13018-019-1114-0

18. Ünver S, Akyolcu N. The effect of hand exercise on reducing the symptoms in hemodialysis patients with carpal tunnel syndrome. Asian J Neurosurg.2018;13(1):31-6. PMID: 29492117; doi: 10.4103/ajns. AJNS_343_16. https://doi.org/10.4103/ajns.ajns_343_16

19. Kang HJ, Koh IH, Lee WY, Choi Y, Hahn S. Does carpal tunnel release provide long-term relief in patients with hemodialysis-associated carpal tunnel syndrome? Clin Orthop Relat Res. 2012; 470(9): 2561-2565. PMID: 22399438. https://doi.org/10.1007/ s11999-012-2309-4
20. Scheltinga MR, Bruijninckx CM. Haemodialysis access-induced distal ischaemia (HAIDI) is caused by loco-regional hypotension but not by steal. Eur J Vasc Endovasc Surg. 2012;43(2):218-23. PMID: 22119228. https://doi.org/10.1016/j.ejvs.2011.10.018

21. Stolic RV1, Trajkovic GZ, Miric DJ, Kisic B, Djordjevic Z, Azanjac GLj, Stanojevic MS, Stolic DZ. Arteriovenous fistulas and digital hypoperfusion ischemic syndrome in patients on hemodialysis. J Nephrol. 2013; 2(2):26-30. https://doi.org/10.5527/wjn.v2.i2.26

22. Azhary H, Farooq MU, Bhanushali M, Majid A, Kassab MY. Peripheral neuropathy: differential diagnosis and management. Am Fam Physician. 2010;81(7):88792. PMID: 20353146.

\section{CORRESPONDÊNCIA}

\section{Renato Nisihara}

Faculdade Evangélica Mackenzie do Paraná, Departamento de Medicina. Curitiba, Paraná, Brasil.

Rua Padre Agostinho, 2770 Bigorrilho, Curitiba-PR 80730-000 